This is the author's final, peer-reviewed manuscript as accepted for publication. The publisher-formatted version may be available through the publisher's web site or your institution's library.

\title{
Enterococcus alcedinis sp. nov., isolated from common kingfisher (Alcedo atthis)
}

Petra Frolková, Pavel Švec, Ivo Sedláček, Ivana Mašlaňová, Jitka Černohlávková, Anuradha Ghosh, Ludek Zurek, Tomáš Radiměřský and Ivan Literák

\section{How to cite this manuscript}

If you make reference to this version of the manuscript, use the following information:

Frolkova, P., Svec, P., Sedlacek, I., Maslanova, I., Cernohlavkova, J., Ghosh, A., Zurek, L., Radimersky, T., \& Literak, I. (2013). Enterococcus alcedinis sp nova, isolated from common kingfisher (Alcedo atthis). Retrieved from http://krex.ksu.edu

\section{Published Version Information}

Citation: Frolkova, P., Svec, P., Sedlacek, I., Maslanova, I., Cernohlavkova, J., Ghosh, A., Zurek, L., Radimersky, T., \& Literak, I. (2013). Enterococcus alcedinis sp nova, isolated from common kingfisher (Alcedo atthis). International Journal of Systematic and Evolutionary Microbiology, 63, 3069-3074.

Copyright: (c) 2014 International Union of Microbiological Societies

Digital Object Identifier (DOI):10.1099/ijs.0.049833-0

Publisher's Link: http://ijs.sgmjournals.org/content/63/Pt 8/3069.abstract

This item was retrieved from the K-State Research Exchange (K-REx), the institutional repository of Kansas State University. K-REx is available at http://krex.ksu.edu 


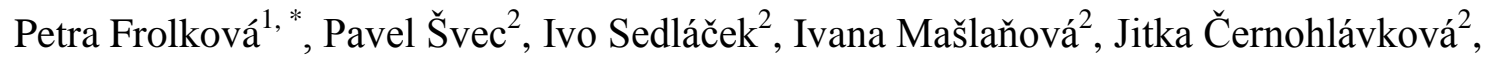
Anuradha Ghosh $^{3}$, Ludek Zurek ${ }^{3}$, Tomáš Radiměřský ${ }^{1}$ and Ivan Literák ${ }^{1,4}$

${ }^{1}$ Department of Biology and Wildlife Diseases, Faculty of Veterinary Hygiene and Ecology, University of Veterinary and Pharmaceutical Sciences, Palackého 1-3, 61242 Brno, Czech Republic

${ }^{2}$ Czech Collection of Microorganisms, Department of Experimental Biology, Faculty of Science, Masaryk University, Tvrdého 14, 60200 Brno, Czech Republic

${ }^{3}$ Department of Diagnostic Medicine and Pathobiology, College of Veterinary Medicine, Kansas State University, Manhattan, KS 66506, USA

${ }^{4}$ CEITEC VFU, University of Veterinary and Pharmaceutical Sciences, Palackého 1-3, 612 42 Brno, Czech Republic

*Corresponding author:

Petra Frolková: Tel.: +420 - 541562 297, E-mail: p.frolkova@ seznam.cz

Running title: Enterococcus alcedinis sp. nov.

Abbreviations: $\operatorname{sodA}$, manganese-dependent superoxide dismutase gene; rep-PCR, repetitiveelement polymerase chain reaction; pheS, phenylalanyl-tRNA synthase alpha subunit gene; rpoA, RNA polymerase alpha subunit gene 
Contents Category: New Taxa; Firmicutes and related organisms

The GenBank database accession numbers for the 16S rRNA gene sequences of Enterococcus alcedinis CCM 8434 and CCM $8433^{\mathrm{T}}$ are JX948101 and JX948102. The GenBank database accession numbers for the sodA gene sequences are JX948095 and JX948096. The GenBank database accession numbers for the $p h e S$ and rpoA gene sequences obtained in this study are JX948097, JX948098 and JX948099, JX948100 respectively.

Seven supplementary figures are available with the online version of this paper.

Two Gram-positive, catalase negative bacterial strains were isolated from the cloaca of common kingfishers (Alcedo atthis). Repetitive sequence-based PCR fingerprinting using the (GTG) $)_{5}$ primer grouped these isolates into a single cluster separated from all known enterococcal species. Both strains revealed identical 16S rRNA gene sequences placing them within the genus Enterococcus with Enterococcus aquimarinus as the closest relative (97.14\% similarity). Further taxonomic investigation using sequencing of the genes for the superoxide dismutase $(\operatorname{sod} A)$, phenylalanyl-tRNA synthase alpha subunit (pheS), and the RNA polymerase alpha subunit (rpoA) as well as application of wholecell protein fingerprinting, automated ribotyping, and extensive phenotyping confirmed that both strains belong to the same species. Based on the polyphasic data, these strains represent a novel species of the genus Enterococcus, for which the name Enterococcus

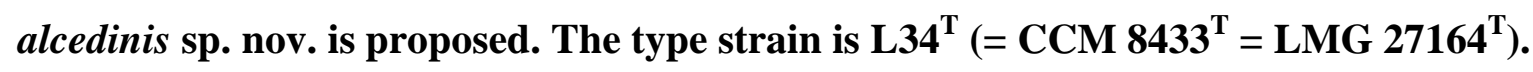

Enterococci are Gram-positive, facultative anaerobic, catalase negative cocci in the family Enterococcaceae (Švec \& Devriese, 2009). They colonize a wide range of different 
environments. Enterococci are natural members of the intestinal microbiota of humans and other mammals. Representatives of this genus have also been reported in birds, reptiles, and insects (Aarestrup et al., 2002; Shoemaker et al., 2006). Moreover, they are widespread in water and on plants. Enterococci are used in manufacturing food products such as starter cultures and probiotics; however, they are also known to cause food spoilage (Aarestrup, 2006) and in recent past, enterococci have became important nosocomial pathogens harboring resistance to multiple antibiotics (Bogaard et al., 2002).

In this study, two enterococcal strains were isolated in the frame of a project dealing with the microbial community of free living birds. The strains L17 and L34 ${ }^{\mathrm{T}}$ originated from the cloaca of two common kingfisher (Alcedo atthis, Alcedinidae) nestlings from the localities

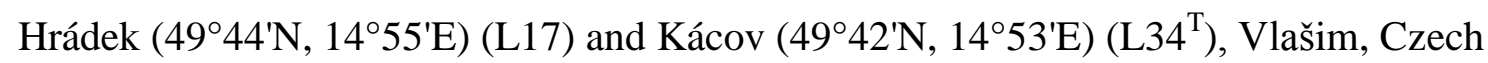
Republic in June, 2009. Cloacal smears were aseptically sampled with sterile cotton swab, placed into Amies transport medium (Oxoid, Hampshire, United Kingdom) and Anaerobe medium (Oxoid), and transported into the laboratory. Samples were cultivated on blood agar (Oxoid) with colistin $\left(10 \mathrm{mg} . \mathrm{l}^{-1}\right)$ and nalidixic acid $\left(10 \mathrm{mg} . \mathrm{l}^{-1}\right)$ at $37^{\circ} \mathrm{C}$ for $48 \mathrm{~h}$. Individual colonies were selected, purified, and stored at $-70^{\circ} \mathrm{C}$. Investigated strains were deposited in the Czech Collection of Microorganisms (CCM) (Masaryk University, Brno, Czech Republic, www.sci.muni.cz/ccm) and in the BCCM/LMG Bacteria Collection (Gent University, Belgium, http://bccm.belspo.be) as L17 (= CCM $8434=$ LMG 27165) and L34 ${ }^{\mathrm{T}}(=\mathrm{CCM}$ $8433^{\mathrm{T}}=$ LMG $27164^{\mathrm{T}}$ ).

Genotypic screening of isolates was performed using rep-PCR fingerprinting with the $(\mathrm{GTG})_{5}$ primer, which was evaluated as a suitable tool for the identification of Enterococcus spp. (Švec et al. 2005). The total genomic DNA isolated by alkaline extraction procedure was amplified by PCR using the (GTG) 5 primer (5'-GTG GTG GTG GTG GTG-3') as described previously (Švec et al., 2008). The resulting fingerprints were processed by the BioNumerics 
v. 6.6 software (Applied-Maths, Sint-Martens-Latem, Belgium), and compared with the inhouse (GTG) $)_{5}$-PCR database of the Czech Collection of Microorganisms containing multiple type and reference strains covering all hitherto described Enterococcus spp. Both isolates revealed identical fingerprints and were grouped in a single cluster separated from all reference strains included in the database. Fig. S1 shows the $(\mathrm{GTG})_{5}$ fingerprints obtained from the isolates and demonstrates their separation from other members of the genus

\section{Enterococcus.}

The 16S rRNA gene was amplified using universal primers EU16SrRNA/F (5'AGAGTTTGATCITGGCTCAG-3') and EU16SrRNA/R (5'ACGGITACCTTGTTACGACTT-3') (Cook \& Mayers, 2003). The initial denaturation was for $1 \mathrm{~min}$ at $94^{\circ} \mathrm{C}$, followed by 30 cycles of denaturation at $90^{\circ} \mathrm{C}$ for $30 \mathrm{~s}$, annealing at $54^{\circ} \mathrm{C}$ for $30 \mathrm{~s}$, and elongation at $72^{\circ} \mathrm{C}$ for $1 \mathrm{~min}$. The final extension step was for $8 \mathrm{~min}$ at $72^{\circ} \mathrm{C}$. A single DNA band with the length of 1500 bp was observed in both strains on $1.5 \%$ agarose gel with ethidium bromide. PCR product was purified with the Jet Quick gel extraction spin kit (Genomed, Löhne, Germany) and Gel/PCR DNA fragments extraction kit (Geneaid, New Taipei City, Taiwan). Quantification of DNA was performed by nanodrop ASP-3700 (ACTGene, Piscataway ,USA), and both strands were sequenced by Macrogen Comp, South Korea. Our sequences and reference sequences obtained from GenBank database were aligned using Bioedit (Hall, 1999) followed by construction of a phylogenetic tree using the neighbour-joining method inferred from 1000 replicates (Saitou and Nei, 1987) with the help of MEGA5 software (Tamura et al., 2011). Strains L17 and L34 ${ }^{\mathrm{T}}$ revealed $100 \% 16 \mathrm{~S}$ rRNA gene sequence similarity to each other. Enterococcus aquimarinus was the closest relative with $97.14 \%$ similarity. Fig. 1 shows the phylogenetic relationships of strains L17 and L34 ${ }^{\mathrm{T}}$ and selected enterococcal species representing different phylogenetic lineages. An elaborate tree containing all recognised enterococcal species is shown in Fig S2. 
Sequencing of the sodA gene was performed according to Frolková et al. (2012). The internal fragment of the $\operatorname{sodA}$ gene was amplified using degenerate primers d1 (5'-CCI TAY ICI TAY GAY GCI YTI GAR CC-3') and d2 (5'-ARR TAR TAI GCR TGY TCC CAI ACR TC-3') (Poyart et al., 2000). Purification of PCR product, quantification of DNA, and sequencing was performed as described above. Our sequences and reference sequences from the GenBank database database were aligned and the phylogenetic tree was constructed as described above. Strains L17 and L34 ${ }^{\mathrm{T}}$ revealed $100 \%$ sodA sequence similarity and were separated from the remaining species of the genus Enterococcus. The closest species was $E$. aquimarinus revealing $82.34 \%$ similarity with the studied strains. The resulting tree based on phylogenetic analysis of the sodA gene is shown in Fig. 2a and the extended tree including all known Enterococcus spp. is shown in Fig. S3.

Sequence analysis based on the partial phenylalanyl-tRNA synthase alpha subunit $(p h e S)$ and RNA polymerase alpha subunit (rpoA) genes has been shown as a valuable tool for the species delineation of enterococci (Naser et al., 2005). Chromosomal DNA isolation, PCR amplification and purification as well as processing of the obtained sequences and construction of the dendrograms using the MEGA5 were performed as described by Švec et al. (2012). Our sequences and reference sequences obtained from the GenBank database database were aligned and the phylogenetic tree was constructed as described above. Results showed high similarity of pheS $(98.73 \%)$ and rpoA (100\%) genes between strains L17 and $\mathrm{L} 34^{\mathrm{T}}$ and differentiated them from the remaining Enterococcus spp. Figs. 2b and 2c demonstrate position of our isolates within the genus Enterococcus resulting from the analysis of pheS and rpoA genes, respectively. Figs. S4 and S5 show extended phylogenetic trees for pheS and rpoA, respectively, including all known Enterococcus spp.

Whole-cell protein fingerprinting proved to correlate well with DNA-DNA hybridization experiments (Vandamme et al., 1996). This method was applied to confirm that 
the investigated strains L17 and $\mathrm{L} 34^{\mathrm{T}}$ are members of the same species and to show that they are different from the phylogenetically closest relative E. aquimarinus. The cells cultivated on Brain Heart Infusion (BHI) agar (Oxoid) for $24 \mathrm{~h}$ at $37^{\circ} \mathrm{C}$ were harvested and disrupted by Labsonic M ultrasonic homogenizer (Sartorius) and the protein extracts were separated using sodium dodecyl sulfate polyacrylamide gel electrophoresis (SDS-PAGE) according to the protocol described by Pot et al. (1994). Numerical analysis of obtained protein profiles was performed using BioNumerics software v.6.6. The resulting dendrogram was constructed using the Pearson's correlations similarity coefficient with the unweighted pair group method using arithmetic averages (UPGMA). Strains $\mathrm{L} 17$ and $\mathrm{L} 34^{\mathrm{T}}$ revealed similar profiles (84\% similarity) confirming that they are members of the same species. Similarity level of $18 \%$ differentiated both strains from the phylogenetically closest species E. aquimarinus represented by strains CCM $7283^{\mathrm{T}}$ and CCM 7284 (Fig. 3).

Automated ribotyping with the EcoRI restriction enzyme was performed using the RiboPrinter microbial characterization system (DuPont Qualicon) in accordance with the standard protocol provided by the manufacturer. Obtained ribopatterns were imported into the BioNumerics v. 6.6 software using a Load samples import script obtained from the manufacturer. The dendrogram was constructed based on calculation of Pearson's correlation coefficients with the UPGMA. Strains $\mathrm{L} 17$ and $\mathrm{L} 34^{\mathrm{T}}$ revealed almost identical profiles (98\% similarity) and were separated from the remaining enterococci. Fig. S6 shows ribotype patterns obtained from analysed strains and demonstrates their differentiation from the type strains of other Enterococcus spp.

Genotyping of isolates L17 and $\mathrm{L} 34^{\mathrm{T}}$ was performed by pulsed-field gel electrophoresis (PFGE) performed according to Ghosh et al. (2012) with several modifications. DNA was digested with $20 \mathrm{U}$ of $S m a \mathrm{I}$ for $4 \mathrm{~h}$ at $37^{\circ} \mathrm{C}$. The PFGE was performed with initial pulse time for $1 \mathrm{~s}$ and final time for $20 \mathrm{~s}$ at $200 \mathrm{~V}$ for $17.5 \mathrm{~h}$. 
Comparison of the PFGE fingerprints was carried out by BioNumerics v. 6.6 software and are shown in Fig. S7. E. faecium ATCC $19434^{\mathrm{T}}$ was used as the reference. Our isolates formed two different pulsotypes which revealed that they are representatives of different strains.

Phenotypic studies on strains $\mathrm{L} 17$ and $\mathrm{L} 34^{\mathrm{T}}$ were performed using conventional tests and commercial identification kits. Catalase production was tested using an ID Colour Catalase kit (bioMérieux, Craponne, France). Motility was studied on a stab-inoculated semisolid medium as described by Švec et al. (2012). Growth at different temperatures and with $6.5 \% \mathrm{NaCl}$ was examined in $\mathrm{BHI}$ broth (Oxoid) for up to 5 days. Lancefield $\mathrm{D}$ antigen was determined using a Strep kit (DiaMondiaL, Dublin, Ireland). Production of gas from glucose and gluconate was tested according to Sperber \& Swan (1976). Extensive phenotypic characterization was performed using commercial identification kits API 20 Strep, API 50 CH and API ZYM (bioMérieux), STREPTOtest 24 (Erba Lachema, Brno, Czech Republic), and Biolog Identification System using GP2 MicroPlate Gram-positive identification test panel (Biolog) according to the manufacturers' instructions. Differentiation of investigated strains from the phylogenetically related E. aquimarinus species may be achieved using a few phenotypic tests. Strains L17 and L34 ${ }^{\mathrm{T}}$ were positive for acetoin production and acidification of 5-ketogluconate and ribose but negative for growth in $6.5 \% \mathrm{NaCl}$, production of $\alpha$ galactosidase and acid production from L-arabinose, melibiose and D-raffinose. Enterococcus aquimarinus revealed opposite results for these tests. Detailed results for the phenotypic characterization of the investigated isolates are mentioned in the species description below.

Determination of GC content of DNA was performed by HPLC. DNA was isolated by modification of the Marmur method (Marmur, 1961), hydrolysed with P1 nuclease and nucleotides were dephosphorylated with bovine alkaline phosphatase (Mesbah et al., 1989). The resulting deoxyribonucleotides were analysed by HPLC System (Shimadzu) following condition as descried earlier (Tamaoka \& Komagata, 1984). Chromatograms were analysed 
using the CLARITY (Version 2.4.1.93) software package (DataApex Ltd.). GC content was calculated from the ratio of deoxyguanosine $(\mathrm{dG})$ and thymidine (dT) according to the method of Mesbah et al. (1989). The DNA G+C content of strain L34 ${ }^{\mathrm{T}}$ was $35.1 \mathrm{~mol} \%$.

The presented polyphasic taxonomic study revealed novel species of the genus Enterococcus, for which the name Enterococcus alcedinis sp. nov. is proposed.

\section{Description of Enterococcus alcedinis sp. nov.}

Enterococcus alcedinis (al.ce'di.nis. N.L. n. Alcedo -inis, Alcedo, a scientific zoological generic name; N.L. gen. n. alcedinis, of Alcedo, isolated from Alcedo atthis (common kingfisher)).

The description of the species is based on two strains. Cells are Gram-positive spherical or ovoid cocci, occurring predominantly in pairs and in short chains or in irregular clusters, non-sporeforming and non-motile. Colonies on BHI agar supplemented by $7 \%$ sheep blood are non-pigmented, circular with whole margins, convex, smooth, glistening, and reach $1-2 \mathrm{~mm}$ in diameter at $37^{\circ} \mathrm{C}$ after $24 \mathrm{~h}$ cultivation. Weak growth of pinpoint colonies with positive esculin reaction was obtained on kanamycin aesculin azide agar at $37^{\circ} \mathrm{C}$ after $24 \mathrm{~h}$. No growth was observed on Slanetz-Bartley agar. The species is a facultative anaerobe and grows at 15 and $42^{\circ} \mathrm{C}$, but not at 10 or $45^{\circ} \mathrm{C}$ or in the presence of $6.5 \% \mathrm{NaCl}$.

Gas production from glucose and gluconate is negative. It does not react with the Lancefield group D antigen antisera. Esculin hydrolysis, Voges-Proskauer test (acetoin), pyrrolidonyl arylamidase, and leucin arylamidase production positive. Hippurate hydrolysis, catalase, urease, and arginin dihydrolase production negative. Chymotrypsin, esterase (C 4), esterase lipase (C 8), lipase (C 14), naphthol-AS-Bi-phosphohydrolase and $\beta$-galactosidase positive. Valine arylamidase, cystine arylamidase, trypsin, $\alpha$-galactosidase, $\beta$-glucuronidase, $\alpha$-glucosidase, $\mathrm{N}$-acetyl- $\beta$-glucosaminidase, $\alpha$-mannosidase and $\alpha$-fucosidase negative. Acid 
is produced from ribose, D-xylose, galactose, glucose, fructose, mannose, mannitol, N-acetylglucosamine, arbutin, salicin, cellobiose, maltose, sucrose, trehalose and 5-keto-gluconate. Acid is not produced from glycerol, erythritol, D-arabinose, L-arabinose, L-xylose, adonitol, $\alpha$-methyl-D-xyloside, sorbose, rhamnose, dulcitol, inositol, sorbitol, $\alpha$-methyl-D-mannoside, $\alpha$-methyl-D-glucoside, amygdalin, melibiose, raffinose, starch, xylitol, $\beta$-gentiobiose, Dlyxose, D-fucose, L-fucose, D-arabitol, L-arabitol, pullulan, gluconate, and 2-keto-gluconate. The variable biochemical reactions revealed by E. alcedinis are as follows. The type strain $\mathrm{L} 34^{\mathrm{T}}$ was positive for acid production from melezitose and delayed positive reactions ( 5 days) were noted for D-tagatose and D-turanose acidification while strains L17 was negative for these three tests. Discrepant results were obtained for $\beta$-glucosidase (positive in STREPTOtest 24 and negative in API ZYM), phosphatase (positive in API ZYM and API 20 Strep while negative in STREPTOtest 24), acid from inulin (positive in STREPTOtest 24 and API 20 Strep and negative in API $50 \mathrm{CH}$ kit), acid from glycogen (positive in API 20 Strep and negative in API $50 \mathrm{CH}$ kit) and acid from lactose (positive in API $50 \mathrm{CH}$ and negative in STREPTOtest 24 and API 20 Strep). The Biolog Identification System with the GP2 MicroPlate test panel revealed the ability to utilize dextrin, N-acetyl-D-glucosamine, arbutin, D-fructose, D-galactose, $\alpha$-D-glucose, D-mannitol, D-mannose, D-psicose, salicin, sucrose, Dtrehalose, inosine, thymidine, and uridine. Negative utilization tests results were recorded for $\alpha$-cyclodextrin, $\beta$-cyclodextrin, glycogen, inulin, mannan, Tween 40 , Tween $80, \mathrm{~N}$-acetyl- $\beta$ D-mannosamine, amygdalin, L-arabinose, D-arabitol, L-fucose, D-galacturonic acid, gentiobiose, D-gluconic acid, m-inositol, $\alpha$-D-lactose, lactulose, maltotriose, D-melezitose, Dmelibiose, $\alpha$-methyl-D-galactoside, $\beta$-methyl- D-galactoside, 3-methyl glucose, $\alpha$-methyl-Dglucoside, $\beta$-methyl-D-glucoside, $\alpha$-methyl-D-mannoside, D-raffinose, L-rhamnose, sedoheptulosan, D-sorbitol, stachyose, D-tagatose, turanose, xylitol, D-xylose, acetic acid, $\alpha$ - 
hydroxybutyric acid, $\beta$-hydroxybutyric acid, $\gamma$-hydroxybutyric acid, $p$-hydroxyphenylacetic acid, $\alpha$-ketoglutaric acid, $\beta$-ketoglutaric acid, lactamide, D-lactic acid methyl ester, L-lactic acid, D-malic acid, L-malic acid, pyruvatic acid methyl ester, succinic acid monomethyl ester, propionic acid, pyruvic acid, succinamic acid, succinic acid, N-acetyl-L-glutamic acid, Lalaninamide, D-alanine, L-alanine, L-alanyl-glycine, L-asparagine, L-glutamic acid, glycyl-Lglutamic acid, L-pyroglutamic acid, L-serine, putrescine, 2,3-butanediol, glycerol, adenosine, 2'-deoxy adenosine, adenosine-5'-monophosphate, thymidine-5'-monophosphate, uridine-5'monophosphate, D-fructose-6-phosphate, $\alpha$-D-glucose-1-phosphate, D-glucose-6-phosphate and D-L- $\alpha$-glycerol phosphate. The DNA G+C content of strain $\mathrm{L}^{3} 4^{\mathrm{T}}$ is $35.1 \mathrm{~mol} \%$.

Type strain $\mathrm{L} 34^{\mathrm{T}}\left(=\mathrm{CCM} 8433^{\mathrm{T}}=\mathrm{LMG} 27164^{\mathrm{T}}\right)$ was isolated from the cloaca of the common kingfisher (Alcedo attis).

\section{Acknowledgements}

This study was supported by the project CEB (CZ.1.07/2.3.00/20.0183) from the Ministry of Education, Youth and Sports of the Czech Republic and the project "CEITEC - Central European Institute of Technology" (CZ.1.05/1.1.00/02.0068) from European Regional Development Fund. We thank Pavel Čech for sampling kingfishers.

\section{References}

Aarestrup, F. M., Butaye, P. \& Witte, W. (2002). Nonhuman reservoirs of enterococci. In The Enterococci: Pathogenesis, Molecular Biology, and Antibiotics Resistance, 1-4. Edited by M. S. Gilmore, D. B. Clewell, P. Courvalin, G. M. Dunny, B. E. Murray \& L. B. Rice. Washington, D. C., ASM Press.

Aarestrup, F. M. (2006): Antimicrobial Resistance in Bacteria of Animal Origin. Washington D. C., ASM Press. 
Bogaard, A. E., Willems, R., London, N., Top, J. \& Stobberingh, E. E. (2002). Antibiotic resistance of faecal enterococci in poultry, poultry farmers and poultry slaughterers. J Antimicrob Chemother 49, 497-505.

Cook, A. E. \& Meyers, P. R. (2003). Rapid identification of filamentous actinomycetes to the genus level using genus-specific 16S rRNA gene restriction fragment patterns. Int J Syst Evol Microbiol 53, 1907-1915.

Frolková, P., Ghosh, A., Švec, P., Zurek, L., Literák, I. (2012). Use of the manganese-dependent superoxide dismutase gene $\operatorname{sodA}$ for rapid identification of recently described enterococcal species. Folia Microbiol 57, 439-42.

Ghosh, A., KuKanich, K., Brown, C. E., \& Zurek, L. (2012). Resident cats in small animal veterinary hospitals carry multi-drug resistant enterococci and are likely involved in cross-contamination of the hospital environment. Front Microbiol 3, 62.

Hall, T. A. (1999). BioEdit: a user-friendly biological sequence alignment editor and analysis program for Windows 95/98/NT. Nucl Acids Symp 41, 95-98.

Marmur, J. (1961). A procedure for the isolation of deoxyribonucleic acid from micro-organisms. $J$ Mol Biol 3, 208-218.

Mesbah, M., Premachandran, U. \& Whitman, W. B. (1989). Precise measurement of the G+C content of deoxyribonucleic acid by high-performance liquid chromatography. Int J Syst Bacteriol 39, 159-167.

Naser, S. M., Thompson, F. L., Hoste, B., Gevers, D., Dawyndt, P.,Vancanneyt, M. \& Swings, J. (2005). Application of multilocus sequence analysis (MLSA) for rapid identification of Enterococcus species based on rpoA and pheS genes. Microbiology 151, 2141-2150.

Pot, B., Vandamme, P. \& Kersters, K. (1994). Analysis of electrophoretic whole-organism protein fingerprints. In Modern Microbiological methods: Chemical methods in prokaryotic systematics, pp. 493-521. Edited by M. Goodfellow \& A. G. O'Donnell. Chichester, UK: John Wiley \& Sons Ltd. 
Poyart, C., Quesnes, G. \&Trieu-Cuot, P. (2000). Sequencing the gene encoding manganesedependent superoxid dismutase for rapid species identification of enterococci. $J$ Clin Microbiol 38, 415-418.

Saitou, N. \& Nei, M. (1987). The neighbor-joining method: a new method for reconstructing phylogenetic trees. Mol Biol Evol 4, 406-425.

Shoemaker, D. M., Simou, J. \& Roland, W. E. (2006). A review of daptomycin for injection (Cubicin) in the treatment of complicated skin and skin structure infections. Ther Clin Risk Manag 2, 169-174.

Sperber, W. H. \& Swan, J. (1976). Hot-loop test for the determination of carbon dioxide production from glucose by lactic acid bacteria. Appl Environ Microbiol 31, 990-991.

Švec, P., Vancanneyt, M., Seman, M., Snauwaert, C., Lefebvre, K., Sedláček, I. \& Swings, J. (2005). Evaluation of (GTG) $)_{5}$-PCR for identification of Enterococcus spp. FEMS Microbiol Lett 247, 59-63.

Švec, P., Nováková, D., Žáčková, L., Kukletová, M. \& Sedláček, I. (2008). Evaluation of (GTG) $)_{5^{-}}$ PCR for rapid identification of Streptococcus mutans. Anton Leeuw Int J G 94, 573-579.

Švec, P. \& Devriese, L. A. (2009). Genus I. Enterococcus (ex Thiercelin and Jouhaud 1903) Schleifer and Kilpper-Bälz 1984, 32VP. In Bergey's Manual of Systematic Bacteriology, The Firmicutes, vol. 3, pp. 594-607. Edited by P. De Vos, G. M. Garrity, D. Jones, N. R. Krieg, W. Ludwig, F. A. Rainey, K. H. Schleifer \&W. B. Whitman. New York: Springer.

Švec, P., Vandamme, P., Bryndová, H., Holochová, P., Kosina, M., Mašlaňová, I. \& Sedláček, I. (2012). Enterococcus plantarum sp. nov., isolated from plants Int J Syst Evol Microbiol 62, $1499-1505$.

Tamaoka, J. \& Komagata, K. (1984). Determination of DNA base composition by reversed-phase high-performance liquid chromatography. FEMS Microbiol Lett 25, 125-128.

Tamura, K., Peterson, D., Peterson, N., Stecher, G., Nei, M. \& Kumar, S. (2011). MEGA5: Molecular evolutionary genetics analysis using maximum likelihood, evolutionary distance, and maximum parsimony methods. Mol Biol Evol 28, 2731-2739. 
Vandamme, P., Pot, B., Gillis, M., DeVos, P., Kersters, K. \& Swings, J. (1996). Polyphasic taxonomy, a consensus approach to bacterial systematics. Microbiol Rev 60, 407-43. 